\title{
GC-MS analysis and Antioxidant Activity of Foeniculum vulgare Mill.
}

\author{
Ram Lal Shrestha, Shree Dhar Gautam*, Binita Maharjan \\ Department of Chemistry, Amrit Campus, Tribhuvan University, Lainchour, Kathmandu, Nepal \\ E-mail:sdgautam72@gmail.com
}

\begin{abstract}
Fruit of Foeniculum vulgare was subjected to extraction of essential oil by hydro distillation in Clevenger apparatus. The compositions of essential oil so collected were determined by GC-MS analysis and it showed the presence of four different compounds. The most abundant were Anethole (77.58\%), DLimonene (11.19\%) and Fenchone (10.47\%). Antioxidant activity of the essential oil of Foeniculum vulgare was studied. Plant extract also showed efficient DPPH antioxidant activity with $I C_{50}=99.2 \pm 2.1 \mathrm{mg} / \mathrm{mL}$.
\end{abstract}

Keywords: Foeniculum vulgare Mill., Essential oil, GC-MS, Antioxidant

\section{Introduction}

Foeniculum vulgare (fennel) belongs to the family Umbelliferae (Apiaceae). It is used to impart flavor to a number of foods, such as soups, sauces, pickles, breads, cakes etc. ${ }^{[1]}$ Fennel is annual, biennial or perennial herbs distributed in central Europe and Mediterranean region. It is widely cultivated throughout the temperate and tropical regions of the world for its aromatic fruits. ${ }^{[2]}$

Foeniculum vulgare has two commercially important fennel types: bitter fennel and sweet fennel. ${ }^{[3]}$ It is growing to a height ranging from 70 to $200 \mathrm{~cm} \cdot{ }^{[4]}$ Fennel plant is glabrous herb with pinnately dissected and segmented linear leaves. Flowers are in compound umbels and yellow. ${ }^{[5]}$

The major components of fennel are phenylpropanoid derivates: trans-anethole and methyl chavicol. Other major components of fennel include $\alpha$-phellandrene, fenchone, and $\alpha$-pinene. ${ }^{[3]}$ Some phenolic compounds such as chlorogenic acid, quercetin-3-O-rutinoside, quercetin-3-O-glucuronide, kaempferol3-O-glucuronide, isoquercitrin, and isorhamnetin-3-O-glucoside are found on fennel. ${ }^{[6]}$

Fruits of fennel are sweet, acrid, bitter, emollient, alexipharmic, expectorant, haematinic, opthalmic, alexipharmic, expectorant, haematinic, opthalmic, intellect-promoting, anthelmintic, carminative, digestive, stomachic, antiemetic, cardiac stimulant, diuretic, vermicidal, galactogogue, antimicrobial and tonic. It is also used to control flatulent dyspepsia and colic in children ${ }^{[5,7]}$ Herbal drugs and essential oils of fennel have hepatoprotective, antispasmodic, anti-inflammatory, analgesic and antioxidant activities. ${ }^{[3]}$

\section{Experimental Methods}

\section{Collection of Plant Materials}

The fruit of fennel plant was collected from Karnali, Nepal. The plants were identified by Department of Botany, Amrit Campus, Lainchour, Kathmandu, Nepal.

\footnotetext{
${ }^{*}$ Corresponding author
} 


\section{Extraction of Essential Oil}

About $0.95 \mathrm{Kg}$ of Foeniculum vulgare fruits were crushed for hydro distillation and subjected to a Clevenger apparatus at $4000 \mathrm{ml}$ of distilled water about four hours. By this process about $6 \mathrm{ml}$ of pale yellow essential oil was collected and stored in a sealed glass vials at low temperature $\left(0-4{ }^{\circ} \mathrm{C}\right)$ prior to analysis.

\section{GC-MS Analysis}

The essential oils sample of Foeniculum vulgare was subjected to GC-MS analysis. GC-MS analysis was performed on a gas chromatography mass spectrometer GCMS-QP2010 under the following condition: injection volume $1 \mu \mathrm{L}$ with split ratio 1:50; Helium as a carrier gas with a Rtx-5MS column of dimension $30 \mathrm{~m} \times 0.25 \mathrm{~mm} \times 0.25 \mu \mathrm{m}$, temperature programmed at 40,200 and $280{ }^{\circ} \mathrm{C}$ with a hold time of 2.0, 3.0 and 4.0 min identification was accompanied by comparison of MS with those reported in NIST 05 and FFNSCI.3 libraries. It was performed in Department of Food Technology and Quality Control, Nepal Government, Babarmahal, Kathmandu, Nepal.

\section{Antioxidant Assay (DPPH method)}

The working solutions $(25,50,100$ and 200$) \mathrm{mg} / \mathrm{ml}$ of the $F$. vulgare oil were prepared in methanol. $0.1 \mathrm{mM}$ of DPPH solution was prepared in dark bottle by mixing $2 \mathrm{mg}$ of DPPH powder in $50 \mathrm{ml}$ of methanol. Briefly $1.5 \mathrm{ml}$ of DPPH solution was mixed in $0.5 \mathrm{ml}$ of different concentrated sample. The mixture was shaken and kept for 30 minutes at room temperature. Their absorbance was taken at $517 \mathrm{~nm}$ against DPPH as a blank. DPPH $(1.5 \mathrm{ml}$ of $0.1 \mathrm{mM})$ and methanol $0.5 \mathrm{ml}$ was used as blank. DPPH Radical Scavenging Activity (\% inhibition) was calculated. $\mathrm{IC}_{50}$ values were measured from \% inhibition versus concentration graph.

\section{Results and Discussion}

\section{GC-MS Analysis}

GC-MS analysis of essential oils of fruits of $F$. vulgare shows the presence of four different compounds. The chemical compounds identified in essential oils of the fruits of the $F$. vulgare plant are presented below:

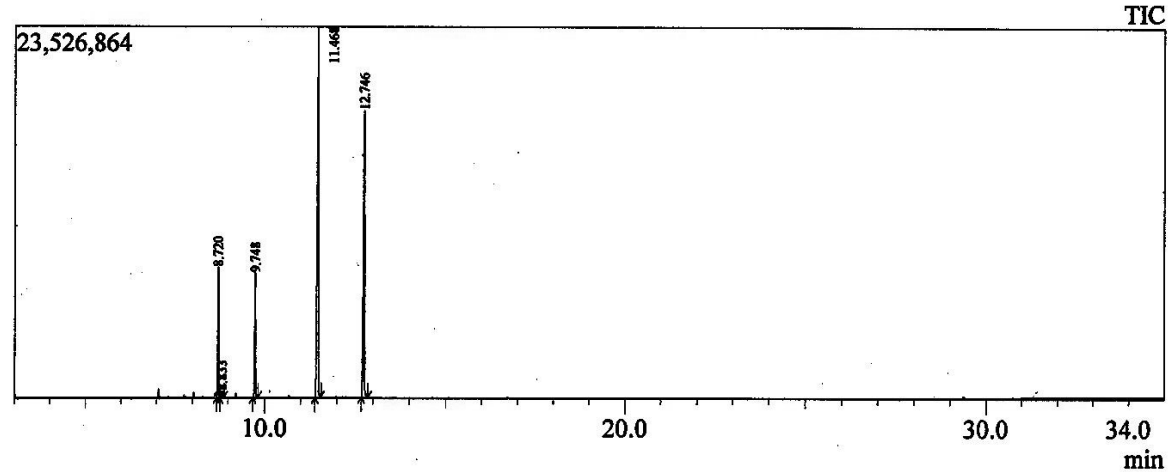

Figure 1: Chromatogram of essential oils of $F$. vulgare

The major constituents present in the essential oils sample were Anethole (77.58\%), D-Limonene $(11.19 \%)$ and Fenchone (10.47\%). Constituents of essential oils of $F$. vulgare are tabulated as follows. 


\section{J. Nepal Chem. Soc., Vol. 37, 2017}

Table 1: List of compounds in essential oils of $F$. vulgare

\begin{tabular}{|l|l|l|l|l|l|l|}
\hline $\begin{array}{c}\text { S.N } \\
.\end{array}$ & \multicolumn{1}{|c|}{ Name of the compounds } & $\begin{array}{c}\text { Molecular } \\
\text { Formula }\end{array}$ & $\begin{array}{c}\text { Molecular } \\
\text { Weight }\end{array}$ & $\begin{array}{c}\text { Retention } \\
\text { Time }\end{array}$ & Area \% & Height \% \\
\hline 1. & D-Limonene & $\mathrm{C}_{10} \mathrm{H}_{16}$ & 136 & 8.720 & 11.19 & 14.21 \\
\hline 2. & $\beta$-Pinene & $\mathrm{C}_{10} \mathrm{H}_{16}$ & 136 & 8.833 & 0.76 & 0.69 \\
\hline 3. & Fenchone & $\mathrm{C}_{10} \mathrm{H}_{16}$ & 152 & 9.748 & 10.47 & 13.53 \\
\hline 4. & Anethole & $\mathrm{C}_{10} \mathrm{H}_{16} \mathrm{O}$ & 148 & 11.468 & 44.68 & 40.37 \\
\hline 5. & Anethole & $\mathrm{C}_{10} \mathrm{H}_{16} \mathrm{O}$ & 148 & 12.746 & 32.90 & 31.21 \\
\hline & & & & & 100.00 & 100.00 \\
\hline
\end{tabular}

The mass spectral data of individual compounds are given below.

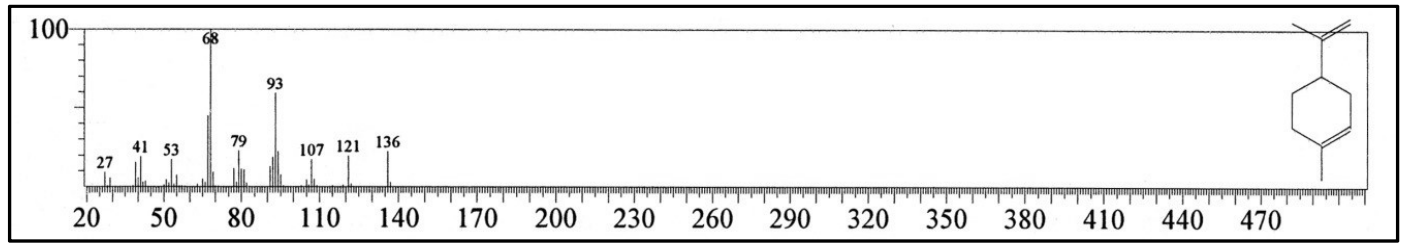

Figure 2: Mass spectral data of D-Limonene

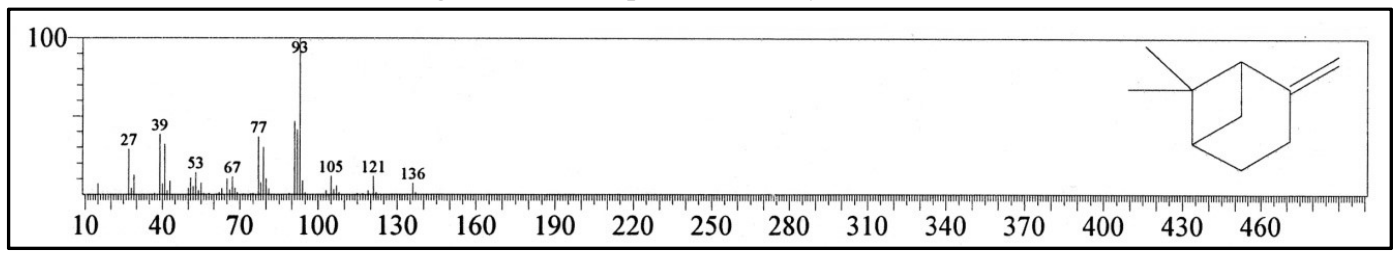

Figure 3: Mass spectral data of $\beta$-Pinene

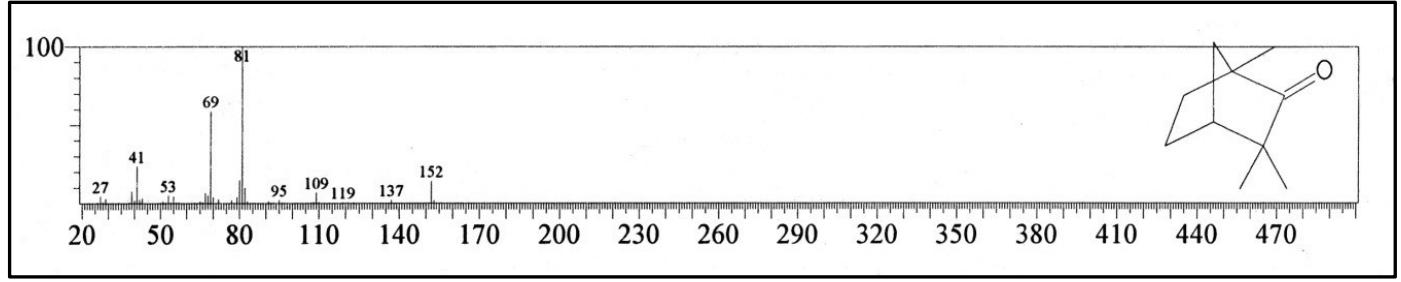

Figure 4: Mass spectral data of Fenchone

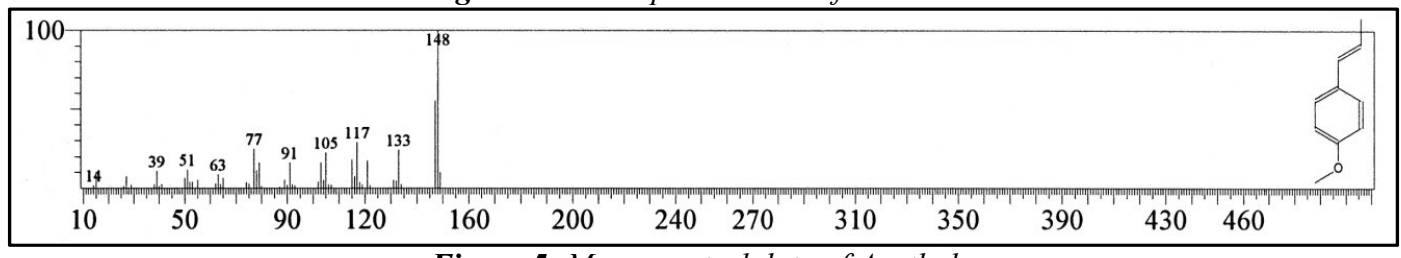

Figure 5: Mass spectral data of Anethole

$-8-$ 


\section{Antioxidant Activity}

The antioxidant potential is in an inverse relation with $\mathrm{IC}_{50}$ value, which can be calculated from linear regression of the $\%$ inhibition verses antioxidant activity. Lower the $\mathrm{IC}_{50}$ value indicates high antioxidant activity.

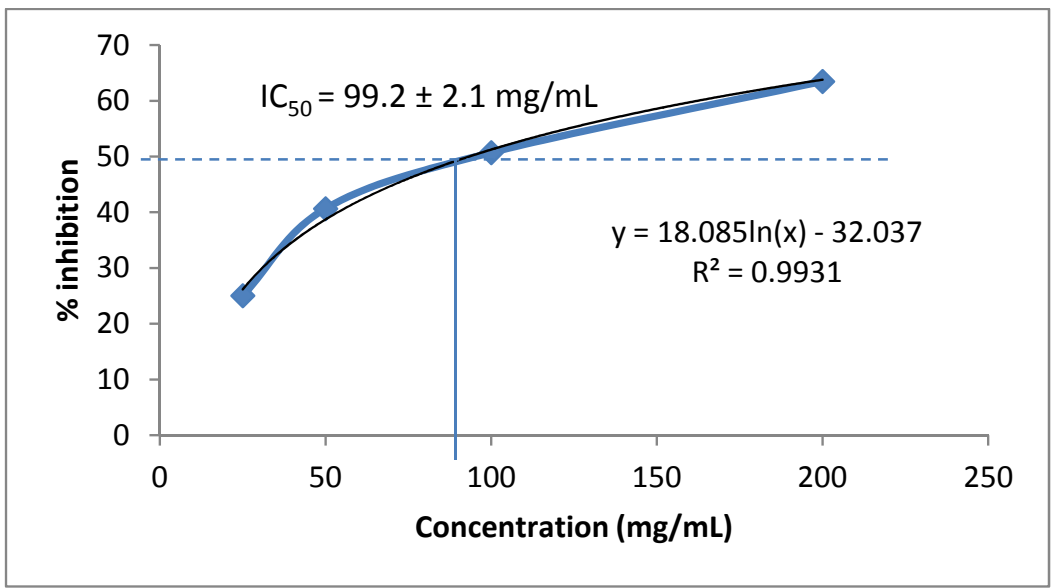

Figure 6: Graphical representation of DPPH assay of the methanolic extract of $F$. vulgare

The $\mathrm{IC}_{50} \pm \mathrm{SEM}$ of the oil was found to be $99.2 \pm 2.1 \mathrm{mg} / \mathrm{mL}$ and the standard quercetin was $2.28 \pm 0.1$ $\mu \mathrm{g} / \mathrm{mL}$.

\section{Conclusion}

GC-MS analysis of essential oils of fruits of $F$. vulgare showed the presence of 4 different compounds. The major constituents present in the essential oils sample were Anethole (77.58\%), DLimonene (11.19\%) and Fenchone (10.47\%). The $\mathrm{IC}_{50} \pm \mathrm{SEM}$ of the essential oil was found to be $99.2 \pm$ $2.1 \mathrm{mg} / \mathrm{mL}$.

\section{Acknowledgments}

We are thankful to Kathmandu Valley School and College, Chhauni, Kathmandu for providing the research lab, Dr. Bishnu Marasini and Ms. Shrimita Shrestha, Department of Biotechnology, National College, Kathmandu for bioactivity test and Mr. Tayer Mohamad Miya, Department of Food Technology and Quality Control, Nepal Government for GC-MS analysis.

\section{References}

1. L. S. Moura, Jr, R. N. Carvalho, M. B. Stefanini, L. C. Ming, \& M. A. A. Meireles, Supercritical fluid extraction from fennel (Foeniculum vulgare): global yield, composition and kinetic data. The Journal of Supercritical Fluids, 2005, 35(3), 212-219.

2. G. Singh, S. Maurya, M. P. De Lampasona, \& C. Catalan, . Chemical constituents, antifungal and antioxidative potential of Foeniculum vulgare volatile oil and its acetone extract. Food Control, 2006 17(9), 745-752. 
3. I. Telci, I. Demirtas, \& A. Sahin,. Variation in plant properties and essential oil composition of sweet fennel (Foeniculum vulgare Mill.) fruits during stages of maturity. Industrial Crops and Products, 2009, 30(1), 126-130.

4. M. M. Ozcan, J. C. Chalchat, D. Arslan, A. Ateş, \& A. Ünver, Comparative essential oil composition and antifungal effect of bitter fennel (Foeniculum vulgare ssp. piperitum) fruit oils obtained during different vegetation. Journal of Medicinal Food, 2006, 9(4), 552-561.

5. S. R. Baral \& P. P. Kurmi A compendium of Medicinal Plants in Nepal. Edn 1, Mass Printing Press, Chhauni, Kathmandu, 2006, 438.

6. I. Parejo, O. Jauregui, F. Sánchez-Rabaneda, F. Viladomat, J. Bastida, \& C. Codina, Separation and characterization of phenolic compounds in fennel (Foeniculum vulgare) using liquid chromatography-negative electrospray ionization tandem mass spectrometry. Journal of Agricultural and Food Chemistry, 2004, 52(12), 3679-3687.

7. S. A. Mahfouz, \&, M. A. Sharaf-Eldin. Effect of mineral vs. biofertilizer on growth, yield, and essential oil content of fennel (Foeniculum vulgare Mill.). International Agrophysics, 2007 21(4), 361. 